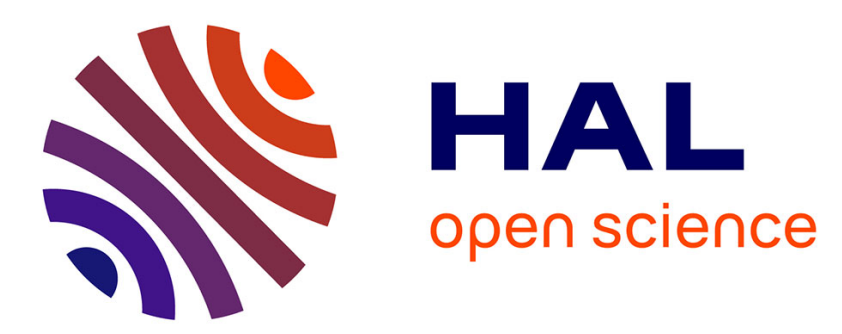

\title{
The multimodality of lexical explanation sequences during videoconferenced pedagogical interaction
}

\author{
Benjamin Holt
}

\section{To cite this version:}

Benjamin Holt. The multimodality of lexical explanation sequences during videoconferenced pedagogical interaction. EUROCALL 2016: CALL Communities \& Culture, Aug 2016, Limassol, Cyprus. 10.14705/rpnet.2016.eurocall2016.559 . hal-02482580

\section{HAL Id: hal-02482580 \\ https://hal.science/hal-02482580}

Submitted on 18 Feb 2020

HAL is a multi-disciplinary open access archive for the deposit and dissemination of scientific research documents, whether they are published or not. The documents may come from teaching and research institutions in France or abroad, or from public or private research centers.
L'archive ouverte pluridisciplinaire HAL, est destinée au dépôt et à la diffusion de documents scientifiques de niveau recherche, publiés ou non, émanant des établissements d'enseignement et de recherche français ou étrangers, des laboratoires publics ou privés. 


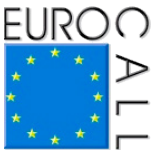

\title{
The multimodality of lexical explanation sequences during videoconferenced pedagogical interaction
}

\author{
Benjamin Holt ${ }^{1}$
}

\begin{abstract}
This study aims to identify and analyze the ways in which semiotic resources are orchestrated by teacher-trainees during videoconferenced French foreign language teaching. Our corpus is made up of six weeks of interaction between seven teacher trainees enrolled in a master's program at Université Lumière Lyon 2 in France and 12 undergraduate business students at Dublin City University in Ireland. 15.5 hours of video data were transcribed using ELAN, and 195 lexical explanation sequences were identified. These sequences were categorized according to whether the lexical problem came from an inability to understand or an inability to speak, and were then split into phases according to a three-step canonical model (Lauzon, 2008). During each phase we look at which semiotic resources were used, combined and co-contextualized by the teacher trainees. Our methodology, which will be used to complete our $\mathrm{PhD}$ project, is outlined here as well as preliminary results.
\end{abstract}

Keywords: videoconferencing, lexical explanation, multimodality.

\section{Introduction}

It has been shown that during native-non-native and non-native-non-native interaction, negotiation sequences are most commonly initiated by lexical triggers (Nicolaev, 2010; Smith, 2003). Various models for negotiation sequences have been proposed (Smith, 2003; Varonis \& Gass, 1985) to describe how a negotiation sequence unfolds in time. Lauzon (2008), for example, presents a three-step canonical model specifically for lexical explanation sequences during teacherstudent interactions. A lexical explanation sequence occurs when the normal progression of a conversation or activity comes to a halt and participants orient

1. Université Lumière Lyon 2, Lyon, France; Benjamin.Holt@univ-lyon2.fr

How to cite this article: Holt, B. (2016). The multimodality of lexical explanation sequences during videoconferenced pedagogical interaction. In S. Papadima-Sophocleous, L. Bradley \& S. Thouësny (Eds), CALL communities and culture-short papers from EUROCALL 2016 (pp. 185-189). Research-publishing.net. https://doi.org/10.14705/rpnet.2016.eurocall2016.559 
their focus towards a lexical item that a learner fails to understand or fails to produce. In the first case, the non-understood lexical item comes from the teacher's discourse or from a pedagogical support such as a video, audio track, text or image. In the second case, failure to produce a lexical item hinders the learner's foreign language output. The teacher must intervene to explain the non-understood lexical item or provide a sufficient one in order for communication to resume. In Lauzon's (2008) three-phase canonical model, there is an opening, a nucleus, and a closing. During the opening phase, the lexical item that is either misunderstood or searched for by the learner is recognized by the participants and problematized. During the nucleus, the teacher attempts to explain the non-understood word or provide the correct word that is being searched for by orchestrating various linguistic and multimodal resources. During the closing phase, the learner's comprehension or ability to properly use the just-provided word is evaluated or ratified by the teacher.

Of interest to us are the ways in which the different phases are multimodally orchestrated by the participants. A multimodal phase (Baldry \& Thibault, 2006) is defined by semiotic coherence. During each phase, different modes (voice, eye contact, posture, proxemics, head movements, facial expressions, gestures, written text, etc.) work together in synergy to make meaning, with the hierarchy of modes constantly being rearranged and renegotiated by the participants (Norris, 2004). According to Norris (2004), a mode has high modal density if it carries most of the meaning at a given time or if communication would come to a halt if it were removed. In a videoconferencing environment such as Visu (Guichon, Bétrancourt, \& Prié, 2012), these modes are channeled through the affordances of the platform. In our case, Visu offers a video channel, an audio channel, a text chat channel, and the ability to send prefabricated instructions and multimedia documents such as images and links to external websites. The aim of this study is to identify what modes are used for what purposes during each phase of lexical explanation sequences and to explore the ways in which the modes interact with each other.

\section{Method}

\subsection{Corpus}

Our corpus, which is part of the ISMAEL project (Guichon, Blin, Wigham, \& Thouësny, 2014), consists of six weeks of videoconferenced interactions mediated by Visu during the fall semester of 2013 between seven future teachers of French enrolled in a master's program for teaching French as a foreign language at 
Université Lumière Lyon 2 in Lyon, France, and 12 undergraduate learners of French at Dublin City University in Dublin, Ireland. These undergraduate business students had a level B1-B2 in French and were preparing to complete an internship the following year in Reims, France. The 40-minute interactions were specifically engineered for business purposes and were centered around themes such as paid vacation, strikes, coffee breaks, professional experience, project management, job interviews, etc. The 28 interactions that were collected have a total time of 15.5 hours and were transcribed using ELAN (Wittenburg et al., 2006).

The verbal and text chat channels were transcribed for all participants for the entire corpus. Next, we identified 195 lexical explanation sequences and split each one into phases using the model mentioned above. The lexical explanation sequences were then divided almost evenly into two main categories: sequences resulting from a comprehension problem and those resulting from a production problem.

\section{Preliminary results and discussion}

Each multimodal environment has a unique palette of semiotic resources, which makes direct comparisons difficult. For this particular multimodal environment, our phase-by-phase preliminary analysis shows that a diverse range of semiotic resources was used during the opening, nucleus and closing phases for different purposes.

Gestures, which play a critical role during classroom foreign language teaching (Tellier, 2008), were put to use during some lexical explanation sequences. In particular, during word searches, teachers sometimes used gesture to verify their own comprehension of the word being searched before providing it. For example, when asked by a learner how to say 'yawning' in French, one teacher trainee, unsure of her own comprehension of the English word, used a gesture to verify it before providing the French translation (see Figure 1, left). For sequences triggered by incomprehension, gestures were used to describe actions, concepts, concrete objects, and even explanation strategies. For example, when explaining the verb 'to strike', one teacher-trainee illustrated the act of chanting slogans by moving his arm up and down in front of the webcam (see Figure 1, center). On many occasions, gestures carried high modal density because they were produced in the absence of speech (such as in the 'yawning' example) and/or deliberately placed directly in front of the webcam. The third teacher-trainee pictured below (see Figure 1, right) rarely made gestures visible to the webcam, but in this case made an effort to make her emblematic gesture visible when illustrating the concept of adding a zero to a monthly paycheck. 
Figure 1. Gestures produced by teacher-trainees during lexical explanation sequences

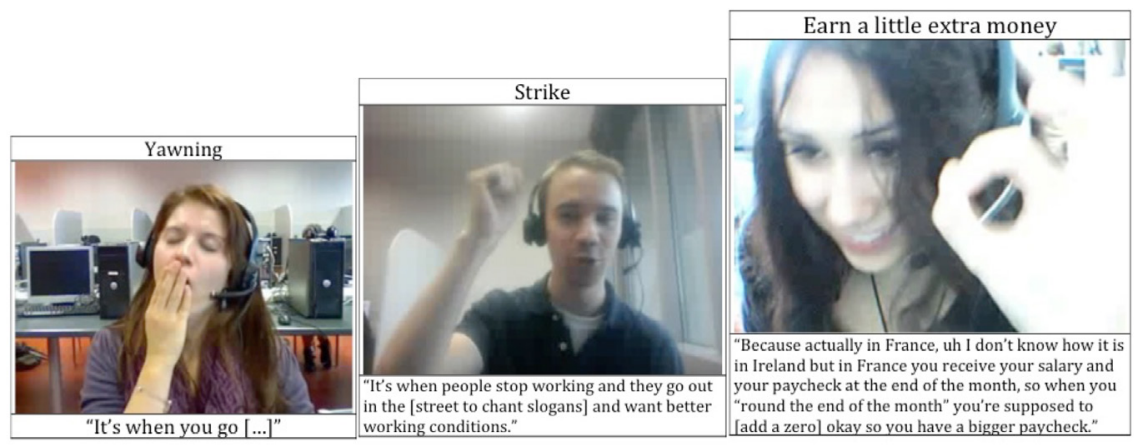

The text chat was used during all three phases. Before incomprehension was manifested, teacher-trainees often anticipated the difficulty of a word by typing it in the text chat window. During the nuclei and closing phases, teacher-trainees used the text chat to type the word that was either just explained or provided in order to offer a visual representation and reinforce memorization. Text messages were not always redundant, often obtaining high modal density when produced in the absence of oral speech. Multimedia documents were also sent during all three phases of lexical explanation sequences having to do with incomprehension, either to present learners with a visual representation before, during or after the explanation.

Finally, we have found synchronization and co-contextualization of resources. The text chat was often co-contextualized by other resources: teacher-trainees regularly said, "I'm putting it in the chat window" or made gestures pointing to the chat window. The sending of documents was similarly co-contextualized by the verbal channel. Teacher-trainees tended not to make hand gestures and send written messages simultaneously due to the difficulty of typing and making gestures at the same time.

\section{Conclusions}

More data must be analyzed in order to proceed to any sort of statistical analysis. Furthermore, facial expressions, eye movements, eyebrow movements and posture, which are important meaning-making resources in face-to-face interaction, still need to be analyzed. For our PhD project, by using the methodology outlined above, we will analyze the entirety of our 195-sequence corpus in order to spot 
patterns, explore variation between the participants, and eventually propose a structural model for videoconferenced lexical explanation sequences similar to the one proposed by Smith (2003) for synchronous text-based negotiation sequences.

\section{Acknowledgements}

We would like to thank the ASLAN project (ANR-10-LABX-0081) of Universite de Lyon, for its financial support within the program 'Investissements d'Avenir' (ANR-11-IDEX-0007) of the French government operated by the National Research Agency (ANR).

\section{References}

Baldry, A., \& Thibault, P. (2006). Multimodal transcription and text analysis. London; Oakville, CT: Equinox Publishing.

Guichon, N., Bétrancourt, M., \& Prié, Y. (2012). Managing written and oral negative feedback in a synchronous online teaching situation. Computer-Assisted Language Learning, 25(2), 181-197. https://doi.org/10.1080/09588221.2011.636054

Guichon, N., Blin, F., Wigham, C., \& Thouësny, S. (2014). ISMAEL learning and teaching corpus.

Dublin, Ireland: Centre for Translation and Textual Studies \& Lyon, France: Laboratoire Interactions, Corpus, Apprentissages \& Représentations.

Lauzon, V. F. (2008). Interactions et apprentissages dans des séquences d'explication de vocabulaire. https://libra.unine.ch/export/DL/Evelyne_Pochon-berger/20434.pdf

Nicolaev, V. (2010). Les négociations de sens dans un dispositif d'apprentissage des langues en ligne synchrone par visioconférence. Les Cahiers de l'Acedle, 7, 169-198.

Norris, S. (2004). Analyzing multimodal interaction: a methodological framework (1st ed.). New York: Routledge.

Smith, B. (2003). Computer-mediated negotiated interaction: an expanded model. The Modern Language Journal, 87, 38-57. https://doi.org/10.1111/1540-4781.00177

Tellier, M. (2008). Dire avec des gestes. Le Français Dans Le Monde: Recherche et Application, 40-50.

Varonis, E. M., \& Gass, S. (1985). Non-native/non-native conversations: a model for negotiation of meaning. Applied Linguistics, 6(1), 71-90. https://doi.org/10.1093/applin/6.1.71

Wittenburg, P., Brugman, H., Russel, A., Klassmann, A., \& Sloetjes, H. (2006). Elan: a professional framework for multimodality research. In Proceedings of LREC (Vol. 2006, p. 5). 


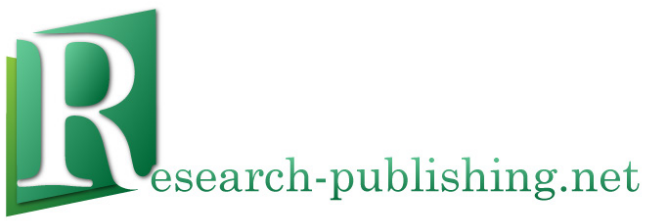

Published by Research-publishing.net, not-for-profit association Dublin, Ireland; Voillans, France, info@research-publishing.net

(C) 2016 by Editors (collective work)

(C) 2016 by Authors (individual work)

\section{CALL communities and culture - short papers from EUROCALL 2016 Edited by Salomi Papadima-Sophocleous, Linda Bradley, and Sylvie Thouësny}

Rights: All articles in this collection are published under the Attribution-NonCommercial -NoDerivatives 4.0 International (CC BY-NC-ND 4.0) licence. Under this licence, the contents are freely available online as PDF files (https://doi. org/10.14705/rpnet.2016.EUROCALL2016.9781908416445) for anybody to read, download, copy, and redistribute provided that the author(s), editorial team, and publisher are properly cited. Commercial use and derivative works are, however, not permitted.

\section{(9) $\Theta \Theta$}

Disclaimer: Research-publishing.net does not take any responsibility for the content of the pages written by the authors of this book. The authors have recognised that the work described was not published before, or that it is not under consideration for publication elsewhere. While the information in this book are believed to be true and accurate on the date of its going to press, neither the editorial team, nor the publisher can accept any legal responsibility for any errors or omissions that may be made. The publisher makes no warranty, expressed or implied, with respect to the material contained herein. While Research-publishing.net is committed to publishing works of integrity, the words are the authors' alone.

Trademark notice: product or corporate names may be trademarks or registered trademarks, and are used only for identification and explanation without intent to infringe.

Copyrighted material: every effort has been made by the editorial team to trace copyright holders and to obtain their permission for the use of copyrighted material in this book. In the event of errors or omissions, please notify the publisher of any corrections that will need to be incorporated in future editions of this book.

Typeset by Research-publishing.net

Cover design by (C) Easy Conferences, info@easyconferences.eu,www.easyconferences.eu

Cover layout by (c) Raphaël Savina (raphael@savina.net)

Photo "bridge" on cover by (C) Andriy Markov/Shutterstock

Photo "frog" on cover by (C) Fany Savina (fany.savina@gmail.com)

Fonts used are licensed under a SIL Open Font License

ISBN13: 978-1-908416-43-8 (Paperback - Print on demand, black and white)

Print on demand technology is a high-quality, innovative and ecological printing method; with which the book is never 'out of stock' or 'out of print'.

ISBN13: 978-1-908416-44-5 (Ebook, PDF, colour)

ISBN13: 978-1-908416-45-2 (Ebook, EPUB, colour)

Legal deposit, Ireland: The National Library of Ireland, The Library of Trinity College, The Library of the University of Limerick, The Library of Dublin City University, The Library of NUI Cork, The Library of NUI Maynooth, The Library of University College Dublin, The Library of NUI Galway.

Legal deposit, United Kingdom: The British Library.

British Library Cataloguing-in-Publication Data.

A cataloguing record for this book is available from the British Library.

Legal deposit, France: Bibliothèque Nationale de France - Dépôt légal: décembre 2016. 